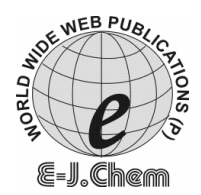

\title{
A Study of Physicochemical Parameters and Nine Heavy Metals in the Euphrates River, Iraq
}

\author{
FIKRAT M. HASSAN*, MAYSOON M. SALEH and JASIM M. SALMAN \\ *College of Science for Women, University of Baghdad, Iraq. \\ College of Science, University of Babylon, Iraq. \\ fik.has@googlemail.com
}

Received 30 June 2009; Revised 20 October 2009; Accepted 15 December 2009

\begin{abstract}
This study was conducted to reveal possible environmental effects on the Euphrates River from the Al-Hindiya barrage to the downstream end of AlKufa city in the middle of Iraq. Seven sites were selected along the study area and sampled during March 2004 to February 2005. We measured physical and chemical properties (air and water temperature, $\mathrm{pH}$, electrical conductivity, TDS, TSS and dissolved oxygen) as well as, concentration and distribution of some heavy metals $(\mathrm{Cd}, \mathrm{Co}, \mathrm{Cr}, \mathrm{Cu}, \mathrm{Fe}, \mathrm{Mn}, \mathrm{Ni}, \mathrm{Pb}$ and $\mathrm{Zn})$ in both dissolved and particulate phases, in the water and sediments (exchangeable and residual phases). The studied area was slightly alkaline, with very hard water and high $\mathrm{BOD}_{5}$. The nutrients showed clear seasonal fluctuations in their concentrations. It was shown that the concentrations of metals in the particulate phase were higher than those in dissolved phase in water. In sediments, the mean concentrations of heavy metals as exchangeable phase were less than in the residual phase.
\end{abstract}

Keywords: Physicochemical parameters, Heavy metals, Euphrates River, Pollution.

\section{Introduction}

As a result of military activities in Iraq since 1980, many military factories were built along the Euphrates and Tigris rivers. These led to an increase in environmental problems, including water contamination, air pollution and ecosystem degradation ${ }^{1}$. Water is polluted artificially by human activities or naturally. In newly reclaimed lands, agricultural and industrial activities may create different sources of pollution ${ }^{2}$. Pollutants that are deposited in the aquatic environment may accumulate in the food chain and cause ecological damage while also posing a risk to human health ${ }^{3}$.

The most toxic pollutants present in the aquatic system are PAHs, heavy metals and organo-chlorines that have detrimental effect on water quality and are harmful to aquatic life $^{4}$. Aquatic organisms are highly sensitive to change in physical and chemical properties of water such as dissolved gases $\left(\mathrm{O}_{2}\right.$ and $\left.\mathrm{CO}_{2}\right), \mathrm{pH}$, alkalinity, hardness and nutrients and to other limnological characteristics ${ }^{5-7}$. Pollutants that are introduced into the environment are distributed in water, sediment, and biota ${ }^{8}$. Heavy metals are naturally introduced into rivers from 
such sources as rock weathering, soil erosion, and the dissolution of water-soluble salts ${ }^{9}$. In natural aquatic systems, sediments play a major role in the control of dissolved metals ${ }^{10}$. Microorganisms and plants can have a profound influence on the chemical reactions of heavy metals ${ }^{11}$ and the heavy metal pollution of aquatic systems is often more obviously reflected in high metal levels in sediments, macrophytes and benthic animals, than in elevated concentrations in water ${ }^{12}$.

Many previous studies showed the concentration and distribution of heavy metals in different aquatic systems. Hwrowitz ${ }^{13}$ studied the heavy metal concentrations in suspended matter of some rivers in the USA such as the Mississippi, Susquehanna and Skunk rivers. Many heavy metals, such as $\mathrm{Cu}$ and $\mathrm{Pb}$, are related to the solid phase at Waihou River in Newzealand ${ }^{14}$. Yilmzer and Yaman ${ }^{15}$ studied water pollution by heavy metals in the Ceyhan River in Turkey and showed the greater values of these metals found in the particulate phase. In another study, Ezeronye and Ubalua ${ }^{16}$ showed there was no relationship between increase of heavy metals and total count of bacteria in a river.

Many studies in different regions of the world have used the sediment of rivers and estuaries as indicators for heavy metals ${ }^{17-19}$. The Euphrates River divides into two branches namely Hindiyah and Al-Hilla in its middle region in Iraq. Its total length is about $2800 \mathrm{~km}$, with $35 \%$ of this river length found in Iraq where it is discharging $818 \mathrm{~m} / \mathrm{sec}^{21}$. Many previous studies investigating physical and chemical characteristics of the Euphrates River, such as Hassan \& $\mathrm{Al}_{-}$Saadi $^{22}$, studied the phytoplankton distribution in the Hilla River and Hassan $^{23,24}$ studied Limnological characters of the Hilla and Diwanyia rivers.

In previous studies, different physical, chemical, biological parameters were used to evaluate the quality of the river and observe the water pollution by heavy metals ${ }^{25-30}$. The present study aims to:

1. Investigate the monthly changes in physical and chemical properties in Al-Hindiyah River (Euphrates River).

2. Determine the concentration and distribution of nine heavy metals in water (dissolved and particulate phase), and sediment (exchangeable and residual phase), and to determine the main sources of heavy metals in the study area.

\section{Experimental}

Seven sites were selected along the Euphrates River (Hindiyah River) between Hindiyah barrage and Al-Kufa town. The study period was between March 2004 and February 2005. Air and water temperature, $\mathrm{pH}$ and electric conductivity were measured in the field using a thermometer, $\mathrm{pH}$ meter (model HANNA) and E.C. meter (Model Bischof L17). Total dissolved solids (TDS), Total solid suspended (TSS), dissolved oxygen, BOD5, total alkalinity, total hardness, calcium, magnesium and sulphate were estimated ${ }^{31}$. Nitrite, nitrate and phosphate were estimated following Parsons ${ }^{32}$, silicate was executed according to Strickland and Parsons ${ }^{33}$.

Heavy metals in water are measured using ion exchange technique procedure to determine the dissolved heavy metals ${ }^{34}$. The particulate heavy metal was measured by digesting particulates collected on Millipore filter membranes of $0.45 \mu \mathrm{m}$ with HCL:

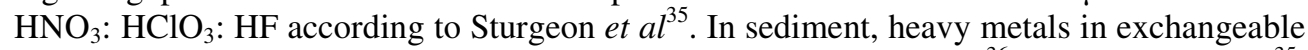
and residual phases were extracted according to Chester \& Voutsinou ${ }^{36}$ and Sturgeon et $\mathrm{l}^{35}$, respectively. These heavy metals determined by flame atomic absorption spectrophotometer (Model Pyeunicam SP9). Total organic carbon and texture of sediment values were determined according to methods of Gaudette $e t a l^{37}$ and Forth \& Turk $^{38}$, respectively.

\section{Results and Discussion}

Air and water temperatures were in the range $6-40{ }^{\circ} \mathrm{C}$ to $10-34{ }^{\circ} \mathrm{C}$, respectively (Table 1 ). Electrical conductivity was observed $110 \mu \mathrm{s} / \mathrm{cm}$ at site 6 and $1100 \mu \mathrm{s} / \mathrm{cm}$ at site 4 respectively . 
Table 1. Physical and chemical characters of water in Euphrates River. (First line: (Mode) Second line: Mean ( \pm S.D)).

\begin{tabular}{|c|c|c|c|c|c|c|c|}
\hline Sits Parameters & Site. 1 & Site. 2 & Site. 3 & Site.4 & Site.5 & Site.6 & Site. 7 \\
\hline \multirow{2}{*}{ Water temperature } & $6-38$ & $8-33$ & $11-37$ & $9-40$ & $6-40$ & $7-36$ & $10-39$ \\
\hline & $25( \pm 9.54)$ & $24( \pm 8.56)$ & $24( \pm 8.41)$ & $25( \pm 10.22)$ & $28( \pm 10.92)$ & $(12.02 \pm) 21$ & $(12.35 \pm) 23$ \\
\hline \multirow{2}{*}{ Air temperature } & $31-10$ & $10-29$ & $11-32$ & $11-34$ & $11-34$ & $10-31$ & $12-30$ \\
\hline & $22( \pm 7.43)$ & $21( \pm 7.22)$ & $21( \pm 7.11)$ & $22( \pm 8.06)$ & $23( \pm 7.63)$ & $19( \pm 9.46)$ & $20( \pm 9.30)$ \\
\hline \multirow[b]{2}{*}{$\mathrm{pH}$} & $7.49-8.9$ & $7.48-8.1$ & $7.2-7.9$ & $7.49-8.0$ & $7.5-7.9$ & $7.2-7.8$ & 7.3-7.9 \\
\hline & $7.8( \pm 0.37)$ & $7.7( \pm 0.16)$ & $7.6( \pm 0.22)$ & $7.7( \pm 0.17)$ & $7.7 \pm 0.14)$ & $7.0( \pm 2.22)$ & $7.0( \pm 2.22)$ \\
\hline \multirow{2}{*}{$\mathrm{EC}, \mu \mathrm{s} / \mathrm{cm}$} & $400-840$ & $460-840$ & $420-900$ & $480-1100$ & $460-900$ & $110-800$ & $470-980$ \\
\hline & $627.5( \pm 151.3)$ & $640( \pm 134.2)$ & $672.5( \pm 134.91)$ & $697.3( \pm 164.4)$ & $654.2( \pm 148.1)$ & $555( \pm 257.6)$ & $617.5( \pm 248.1)$ \\
\hline \multirow{2}{*}{ TDS, mg/L } & $517-890$ & $561-960$ & $532-1057$ & 566-1022 & $510-1050$ & $650-1045$ & $660-1165$ \\
\hline & $733.4( \pm 116.0)$ & $744.9( \pm 115.0)$ & $776.3( \pm 153.1)$ & $783.9( \pm 150.4)$ & $773.7( \pm 150.3)$ & $771.7( \pm 271.2)$ & $743.0( \pm 271.6)$ \\
\hline \multirow{2}{*}{ TSS, mg/L } & $3.10-33.50$ & $1.90-58.60$ & $0.30-35.70$ & $0.60-32.20$ & $0.1-45.6$ & $1.3-28.4$ & 2.4-20.7 \\
\hline & $14.9( \pm 9.2)$ & $13.9( \pm 16.4)$ & $10.8( \pm 9.1)$ & $9.4( \pm 9.9)$ & $11.7( \pm 12.7)$ & $9.2( \pm 7.7)$ & $9.5( \pm 6.7)$ \\
\hline \multirow{2}{*}{$\mathrm{DO}, \mathrm{mg} / \mathrm{L}$} & $3.1-11.8$ & $4.0-11.6$ & $5.0-10.6$ & $4.4-12.4$ & $4.6-13.0$ & $5.6-11.0$ & $4.8-11.4$ \\
\hline & $7.7( \pm 2.8)$ & $7.7( \pm 2.7)$ & $7.6( \pm 1.8)$ & $8.0( \pm 2.5)$ & $8.8( \pm 2.4)$ & $7.1( \pm 3.0)$ & $6.9 \pm(3.0)$ \\
\hline \multirow{2}{*}{$\%$ Saturation of DO } & $46.0-148.0$ & $42.5-149.0$ & $45.4-135.0$ & $42.7-158.0$ & $46.7-172.0$ & $49.6-135.6$ & $44.5-145.6$ \\
\hline & $94.4( \pm 35.2)$ & $89.3( \pm 36.7)$ & $87.2( \pm 28.0)$ & $93.9( \pm 34.2)$ & $105.1( \pm 38.4)$ & $79.8( \pm 36.0)$ & $80.1( \pm 39.2)$ \\
\hline \multirow{2}{*}{$\mathrm{BOD}_{5}, \mathrm{mg} / \mathrm{L}$} & $1.4-6.8$ & $0.20-6.6$ & $0.8-5.0$ & $0.6-8.0$ & $1.6-6.6$ & $1.0-6.7$ & $1.8-6.6$ \\
\hline & $3.7( \pm 2.0)$ & $3.0( \pm 2.0)$ & $2.9( \pm 1.2)$ & $3.5( \pm 2.3)$ & $3.7( \pm 1.8)$ & $3.2( \pm 1.9)$ & $3.6( \pm 1.9)$ \\
\hline Total alkalinity & $103-153$ & $102.0-150.0$ & $101.0-152.0$ & $103.0-152.0$ & $91.0-153.0$ & $106.0-167.0$ & $100.0-154.0$ \\
\hline $\mathrm{mg}(\mathrm{CaCO} 3) / \mathrm{L}$ & $12.31( \pm 13.6)$ & $119.5( \pm 12.5)$ & $117.1( \pm 16.3)$ & $118.7( \pm 16.1)$ & $121.0( \pm 6.19)$ & $117.0( \pm 40.1)$ & $114.3( \pm 39.1)$ \\
\hline Total hardness & $370.0-800.0$ & $250.0-670.0$ & $210.0-720.0$ & $350.0-710.0$ & $270.0-810.0$ & $310.0-800.0$ & $320.0-820.0$ \\
\hline $\mathrm{mg}(\mathrm{CaCO} 3) / \mathrm{L}$ & $588.3( \pm 144.2)$ & $530.8( \pm 113.8)$ & $544.1( \pm 135.0)$ & $571.6( \pm 113.7)$ & $553.3( \pm 125.5)$ & $570.8( \pm 227.7)$ & $566.6( \pm 221.8)$ \\
\hline \multirow{2}{*}{$\mathrm{Ca} \mathrm{mg}(\mathrm{CaCO} 3) / \mathrm{L}$} & $108.2-192.3$ & $96.6-232.4$ & $112.2-208.4$ & $56.1-208.4$ & $116.2-260.5$ & $96.1-240.0$ & 208.4-112.2 \\
\hline & $142.9( \pm 27.2)$ & $143.6( \pm 33.4)$ & $148.2( \pm 33.8)$ & $136.2( \pm 39.4)$ & $156.6( \pm 42.3)$ & $135.2( \pm 58.1)$ & $135.2( \pm 52.5)$ \\
\hline \multirow{2}{*}{$\mathrm{Mg}, \mathrm{mg}(\mathrm{CaCO} 3) / \mathrm{L}$} & $4.7-120.0$ & $13.2-82.7$ & $12.1-108.2$ & $2.3-106.8$ & $9.6-104.6$ & $1.3-113.0$ & $72.3-116.7$ \\
\hline & $59.0( \pm 38.6)$ & $52.1( \pm 25.2)$ & $58.4( \pm 31.8)$ & $56.4( \pm 40.4)$ & $60.2( \pm 28.6)$ & $72.9( \pm 36.2)$ & $75.3( \pm 26.5)$ \\
\hline \multirow{2}{*}{ Nitrate, $\mu \mathrm{g} / \mathrm{L}$} & $0.06-1.3$ & $0.06-0.8$ & $0.07-0.5$ & $0.01-1.1$ & $0.06-0.6$ & $0.06-0.08$ & $0.06-0.4$ \\
\hline & $0.19( \pm 0.36)$ & $0.1( \pm 0.2)$ & $0.13( \pm 0.17)$ & $0.1( \pm 0.3)$ & $0.14( \pm 0.18)$ & $0.6( \pm 0.2)$ & $0.9( \pm 0.1)$ \\
\hline \multirow{2}{*}{ Nitrite, $\mu \mathrm{g} / \mathrm{L}$} & $3.8-278.0$ & $6.8-265.0$ & $6.2-360.9$ & $4.3-249$ & $3.6-267.0$ & $4.5-173.0$ & $1.0-100.0$ \\
\hline & $70.8( \pm 95.4)$ & $99.1( \pm 95.4)$ & $92.1( \pm 108.3)$ & $74.7( \pm 73.3)$ & $67.6( \pm 78.2)$ & $39.1( \pm 47.8)$ & $32.9( \pm 34.0)$ \\
\hline \multirow{2}{*}{ Phosphate, $\mu \mathrm{g} / \mathrm{L}$} & $0.0-0.7$ & $0.0-0.7$ & $0.0-0.7$ & $0.0-0.7$ & $0.0-0.7$ & $0.0-0.6$ & $0.0-0.6$ \\
\hline & $0.5( \pm 0.1)$ & $0.5( \pm 0.1)$ & $0.5( \pm 0.1)$ & $0.5( \pm 0.1)$ & $0.5( \pm 0.1)$ & $0.4( \pm 0.2)$ & $0.4( \pm 0.2)$ \\
\hline \multirow{2}{*}{ Sulphate, mg/L } & 27.7-1805.0 & $21.1-1114.0$ & $28.5-1010$ & $24.0-995.54$ & $20.7-892.0$ & $97.2-1130.0$ & $93.2-1100.0$ \\
\hline & $626.6( \pm 538.8)$ & $483.2( \pm 356.3)$ & $466.6( \pm 330.2)$ & $447.9( \pm 296.7)$ & $471.1( \pm 284.4)$ & $478.9( \pm 360.8)$ & $485.0( \pm 369.7)$ \\
\hline \multirow{2}{*}{ Silicate, $\mu \mathrm{g} / \mathrm{L}$} & $140.3-830.0$ & $123.4-1012$ & 54.4-1038.0 & $55.1-1466.0$ & $53.13-1542.0$ & $39.8-1271.0$ & $49.8-775.0$ \\
\hline & $36.5( \pm 265.2)$ & $420.5( \pm 308.3)$ & $449.0( \pm 287.0)$ & $435.3( \pm 405.2)$ & $467.1( \pm 436.2)$ & $402.1( \pm 391.6)$ & $349.2( \pm 291.3)$ \\
\hline
\end{tabular}


During the study period, $\mathrm{pH}$ was in the ranges from 7.2 to 9.9, TDS and TSS ranged from $510-1165$ and $0.10-58.60 \mathrm{mg} / \mathrm{L}$ respectively, these values increased in winter months and decreased in summer months ${ }^{39-42}$.

The solubility of oxygen in an aquatic system is influenced the temperature and dissolved salts ${ }^{43}$. Highly variable concentrations of dissolved oxygen were recorded at the study sites between $3.1 \mathrm{mg} / \mathrm{L}$ at site 2 and $13 \mathrm{mg} / \mathrm{L}$ at site 5 (Table 1). The result showed no significant differences among the sites.

High values of $\mathrm{BOD}_{5}$ were recorded in most study sites and these exceed limits recommended by $\mathrm{WHO}^{44}$. This may be due to direct discharge of sewage into the river at the study sites ${ }^{45,46}$. Total alkalinity ranged between $91 \mathrm{mg} \mathrm{CaCo}_{3} / \mathrm{L}$ and $167 \mathrm{mg} \mathrm{CaCO} / \mathrm{L}$ (Table 1). Positive correlations were recorded between total alkalinity and both dissolved oxygen and $\mathrm{BOD}_{5}(\mathrm{r}=0.560, \mathrm{p}<0.01$ and $\mathrm{r}=0.572, \mathrm{p}=0.01$, respectively. Many studies have found that Iraqi water was slightly alkalinity $\mathrm{y}^{22,23,40,47}$.

The present study found high concentrations of total hardness in all sites during different months. It ranged between $210 \mathrm{mg} \mathrm{CaCO} / / \mathrm{L}$ and $820 \mathrm{mg} \mathrm{CaCO} / \mathrm{L}$, with no significant difference among study sites while there were a negative correlation with temperature and dissolved oxygen $(\mathrm{r}=0.531, \mathrm{P}<0.01$ and $\mathrm{r}=-0.517, \mathrm{P}<0.01$, respectively).

Calcium value ranged from 56.10-260.50 $\mathrm{mg} \mathrm{CaCO}_{3} / \mathrm{L}$, while magnesium concentration ranged from 1.3-120 $\mathrm{CaCO}_{3} / \mathrm{L}$. There were no significant differences between sites and months, and there was no correlation between calcium and magnesium.

High magnesium values may be a result of soil erosion ${ }^{23}$ or to a high density of phytoplankton ${ }^{49}$. The values of nitrite and nitrate ranged from $0.064-1.3 \mu \mathrm{g} / \mathrm{L}$ and $1-360.95 \mu \mathrm{g} / \mathrm{L}$ respectively and no significant differences between sites. There were significant differences between months. The results recorded positive correlations between nitrate with dissolved oxygen, $\mathrm{BOD}_{5}$, total alkalinity and nitrite $(\mathrm{r}=0.800, \mathrm{P}<0.01 ; \mathrm{r}=0.642, \mathrm{p}<0.01 ; \mathrm{r}=0.591$, $\mathrm{P}<0.01 ; \mathrm{r}=0.820, \mathrm{P}<0.01)$ respectively.

The variation in nitrate concentration may be due to the input from groundwater, plant fertilizers, pesticides and other pollutants to the river ${ }^{50}$.

Soluble reactive phosphate in most sites was low or ND, but values to $0.77 \mu \mathrm{g} / \mathrm{L}$ were recorded. Low concentrations may be due to precipitation on sediment ${ }^{51}$ or accumulation in aquatic plant and phytoplankton ${ }^{52}$.

The sulfate values ranged from 20.76-1805 mg/l (Table 1), while silicate ranged from 39.8-1542 $\mu \mathrm{g} / \mathrm{L}$. A significant difference was recorded among months and also there was a negative correlation with $\mathrm{pH}$ and $\mathrm{EC},(\mathrm{r}=-0.614, \mathrm{P}<0.01 ; \mathrm{r}=-0.586, \mathrm{P}<0.01$, respectively) and positive correlations with air and water temperature and $\mathrm{BOD}_{5}(\mathrm{r}=0.849, \mathrm{P}<0.01 ; \mathrm{r}=0.902$, $\mathrm{P}<0.01 ; \mathrm{r}=0.502, \mathrm{P}<0.01$, respectively).

The present study showed high values of silicate through the summer and autumn that may be because of the decay of diatoms by high temperature ${ }^{43}$ or by increase in the solubility of metal salts in water ${ }^{53}$, this result agrees with many studies in Iraqi aquatic systems $^{23,24,27}$.

Table 2 show the concentration of heavy metals in water and sediments in Euphrates River. The dissolved heavy metals ranged between the lowest limit for $\mathrm{Ni} \& \mathrm{~Pb}(0.06 \mu \mathrm{g} / \mathrm{L})$ and the highest limit for $\mathrm{Fe}(103.9 \mu \mathrm{g} / \mathrm{L})$. While, the particulate heavy metals ranged between $0.1 \mu \mathrm{g} / \mathrm{g}$ for $\mathrm{Cr}$ and $617 \mu \mathrm{g} / \mathrm{g}$ for Fe. 
Table 2. Means of heavy metals concentration in water and sediments in the study area.

\begin{tabular}{crrccc}
\hline & \multicolumn{2}{c}{ Water } & \multicolumn{3}{c}{ sediment } \\
\cline { 2 - 6 } Element & $\begin{array}{c}\text { Dissolved } \\
\mu \mathrm{g} / \mathrm{L}\end{array}$ & $\begin{array}{c}\text { Particulate } \\
\mu \mathrm{g} / \mathrm{g}\end{array}$ & $\begin{array}{c}\text { Residual } \\
\mu \mathrm{g} / \mathrm{g}\end{array}$ & $\begin{array}{c}\text { Exchangeable } \\
\mu \mathrm{g} / \mathrm{g}\end{array}$ & $\begin{array}{c}\text { Total } \\
\mu \mathrm{g} / \mathrm{g}\end{array}$ \\
\hline $\mathrm{Cd}$ & 2.14 & 10.20 & 5.50 & 5.72 & 11.22 \\
$\mathrm{Co}$ & 1.16 & 8.09 & 4.34 & 3.90 & 8.24 \\
$\mathrm{Cr}$ & 0.07 & 0.24 & 0.24 & 0.15 & 0.47 \\
$\mathrm{Cu}$ & 2.48 & 13.60 & 7.10 & 7.34 & 14.14 \\
$\mathrm{Fe}$ & 105.60 & 660.00 & 351.90 & 309.80 & 661.70 \\
$\mathrm{Mn}$ & 6.12 & 33.70 & 18.84 & 18.86 & 37.70 \\
$\mathrm{Ni}$ & 0.07 & 0.19 & 0.10 & 0.27 & 0.37 \\
$\mathrm{~Pb}$ & 0.10 & 0.50 & 0.32 & 0.27 & 0.59 \\
$\mathrm{Zn}$ & 10.50 & 59.90 & 38.72 & 28.94 & 67.66 \\
\hline
\end{tabular}

The concentrations of some heavy metals in water of Euphrates River were low according to WHO and USEPA guidelines, but there were high compared to other Iraqi aquatic systems $^{54-56}$. This difference with other Iraqi studies may be related to the difficulty of investigating heavy metals in toxic aquatic system, where heavy metal concentrations will be low. Moreover the many factors affect the concentrations, such as: the flow of the dredged materials from upper regions of the river, dilution and increase of water flow, direct drainage from farmlands, factories, sewage disposal plants, dissolution of sediments, increases in the numbers of phytoplankton in water, bioaccumulation, chemical adsorption on sediments and complexes with organic matter ${ }^{57-60}$.

The results of this study showed positive correlation between heavy metals in dissolved and particulate phases and positive correlation with air and water temperature, dissolved oxygen, $\mathrm{BoD}_{5}$ and with sulphate and silicate.

The concentration of heavy metals in the particulate phase were $\mathrm{Ni}<\mathrm{Cr}<\mathrm{Pb}<\mathrm{Co}<\mathrm{Cd}$ $<\mathrm{Cu}<\mathrm{Mn}<\mathrm{Zn}<\mathrm{Fe}$.

High concentrations of heavy metals were recorded in exchangeable and residual sediment. This concentration ranged between $0.1 \mu \mathrm{g} / \mathrm{g}$ for $\mathrm{Cr}$ and $308.46 \mu \mathrm{g} / \mathrm{g}$ for $\mathrm{Fe}$ (exchangeable phase) and $0.09 \mu \mathrm{g} / \mathrm{g}$ for $\mathrm{Ni}$ and $351.9 \mu \mathrm{g} / \mathrm{g}$ for Fe. The dissolved elements are transformed into particulate matter through uptake by phytoplankton, oxidation and adsorption in the basins ${ }^{58}$.

Positive correlations were found between some heavy metals and dissolved oxygen, $\mathrm{BOD}_{5}$, nitrite, nitrate, reactive phosphate and silicate. The increase of heavy metal concentration may be due to multiple source of pollution such as sewage, pesticides, industrial waste, etc. $^{18}$, or by decomposition of plankton, diatoms and benthic organism ${ }^{58}$. Many other factors affect heavy metal concentration in sediments, such as grain size and percentage of total organic carbon (\% TOC $)^{61}$. The results showed that sediment texture in Euphrates River was sand-silt-clay in most sites (Figure 1) and that there was high in TOC\% (Figure 2), but there was no significant difference between TOC and heavy metals in sediment. The behavior and distribution of heavy metals in sediments may be affected by water hydrology, domestic discharge and many biological, chemical and geological operations in aquatic system ${ }^{62}$. 


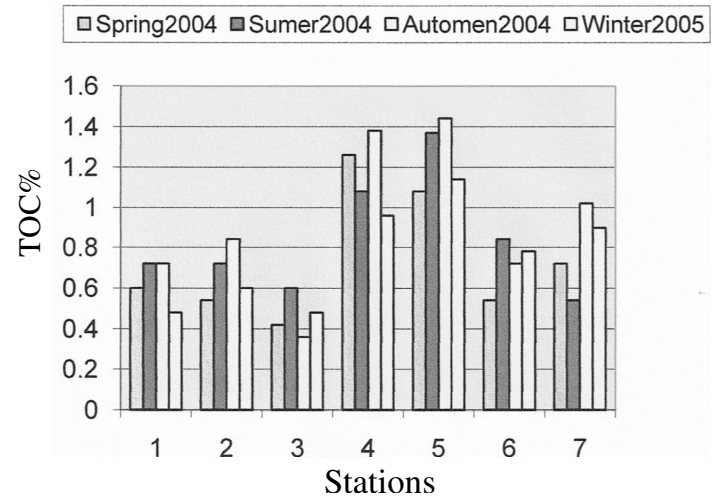

Figure 1. Seasonal variations for percentage of total organic carbon (TOC) in sediment at the study area.

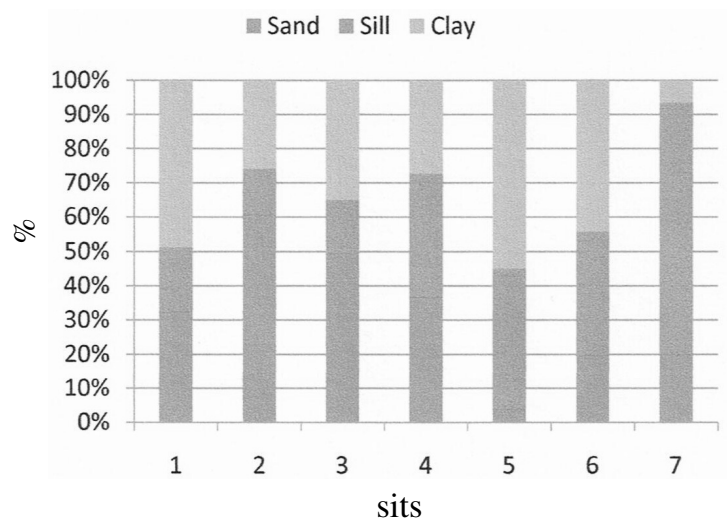

Figure 2. Percentage of sedimenat texture at the study area.

\section{Conclusions}

The waste of military factories, urban run-off, city sewage and the agricultural activities were affecting the physicochemical characteristics of Euphrates River. The heavy metals were accumulated in the sediment of river and it was shown in this study. The mean concentrations of studied metals in particulate phase were higher than those in dissolved phase in water.

\section{References}

1. Hassan F M, Iraqi National J Chem., 2004, 14, 224.

2. Taha A A, El-Mohmoudi A S and El-Haddad I M, Emirates Journal for Engineering Research, 2004, 9(1), 35.

3. Van den Broek J L, Gledhill K S and Morgan D G, UTS Freshwater Ecology Report 2002, Department of Environmental Sciences, University of Technology, Sydney, 2002, 1-25.

4. Clark R B, Marine pollution. $4^{\text {th }}$ Edition, Clarendon Press, Oxford, 1997, 161.

5. King L, Barker P and Jones R, Freshwater Biology, 2000, 45, 425.

6. Polate $\mathrm{S}$ and Isik Oya, Turk J Bot., 2002, 26, 77-86.

7. Morales J A, Albornoz A, Socorro E and Morillo A, Water, Air, Soil Pollut., 2001, 128, 207.

8. Barstye Lovejoy D, Acta Zoological Lituanica, 1999, 9(2), 12. 
9. Garbarino J R, Hayes H C, Roth D A, Antweiler R C, Brinton T I. and Taylor H E, Heavy metals in the Mississippi River, in : Meade, R.H, Ed, Contaminants in the Mississippi River, 1987-92, U.S. Geological Survey Circular, 1995, 1133, 52-71.

10. Bordas F and Bourg A, Water, Air Soil Pollut., 2001, 128, 391.

11. Brown G E, Jr Foster A. L nad Ostergren J D, Proc Nat Acad Sci USA, 1999, 96, 3388.

12. Linnik P M and Zubenko I B, Lakes \& Reservoirs: Research \& Management, 2000, 5, 11.

13. Horowitz A J, Environ Sci Technol., 1986, 20(2), 155.

14. Webster J G, New Zealand J Marine and Freshwater Research, 1995, 29, 539.

15. Yilmazer D and Yaman S, Tr J Engineering and Environmental Science, 1999, 23, 59.

16. Ezeronye O U and Ubalua A O, African J Biotech, 2005, 4(3), 266.

17. El-Sammak A A adn El-Sabrouti M A, Qater Univ Sci J., 1995, 15(2),451.

18. Callender E and Rice K C, Environ Sci Technol., 2000, 34(2), 232.

19. Binning K and Baird D, Water SA., 2001, 27(4), 461.

20. Ho S T, Tsai L J and Yu K C, in: Bruen M, (Ed.) Proceedings of the $7^{\text {th }}$ International Specialised IWA Conference, Dublin, Ireland, 2003, 4. 1140.

21. UNESCO, A statistical Review No.108, 2002.

22. Hassan F M and AL-Saadi H A, Iraq J Coll Educ For Woman Univ Baghdad, 1995, 6 (2), 55.

23. Hassan F M, J Sci., 1997, 8(1), 22.

24. Hassan F M, J Um Salama for Science, 2004 1(1), 119.

25. Hassan, F M, Taylor, W D, Al-Taee, M M S and Al-Fatlawi, H J J, J Environ Biol., 2010, 31(2), 343.

26. Al-Saadi H A, Hassan, F M and Alkam, F M, J Dohuk Univ., 2008, 11(1), 67.

27. Al-Saadi, H A, Al-Lami, A A, and Kassim, T I, Regulated Rivers-Research \& Management, 1996, 12(1), 27-38

28. Hussein F H, Al-Tee M M, Alkhateeb A N and Abid F M, Asian J Chem., 2007, 19(1), 724.

29. Al-Tee M M, Alkhateeb A N, Hussein F H and Abid F M, Asian J Chem., 2007, 19(1), 741 .

30. Hassan F M, Kathim N F and Hussein F H, E Journal of Chemistry, 2008, 5(2), 323-330.

31. APHA, Standard Methods for the Examination of Water and Wastewater. $20^{\text {th }}$. Ed. American Public Health Association, Washington, DC, 1985.

32. Parsons T R, Mait Y and Laulli C M, A manual of chemical and biological methods for seawater analysis, Pergamone Press Oxford, 1984.

33. Strickland J D and Parsons T R, A Practical Handbook of Seawater Analysis, Bull Fish Res Bd Canada, 1972, 167, p310.

34. Riley J P and Taylor D, Anal Chim Acta, 1968, 40, 479.

35. Sturgeon R E, Desaulincrs J A, Berman S S and Russell D S, Anal Chem Acta., 1982, 134, 288.

36. Chester R and Voutsinon F G, Mari Pollut Bull., 1981, 12(3), 84.

37. Gaudette H E, Flight W R, Toner L and Folger D W, J Sediment Petrol, 1974, 44(1), 249.

38. Foth H D and Turk L M, Fundamentals of Soil Science. New York, John Wiley \& Sons, Inc. 1972, 454.

39. Wetzel R G, Limnology, lake and river ecosystems. $3^{\text {th }}$ Ed. Academic Press, An Elsevier Science imprint, SanFrancisco, New York, London. 2001, 729.

40. Al-Saadi, H A, Kassim T I, Al-Lami A A and Salman S K, Limnologica, 2000, 30, 83. 
41. Hassan F M, Al-Saadi H A and Mohamed A A K, Nat J Chem., 2001, 4, 549.

42. Al-Mousawi A H, Al-Saadi H A and Hassan F M, Bas J Sci., 1994, 12(1), 9.

43. Wetzel R $\mathrm{G}$ and Likens $\mathrm{G}$ E, Limnological analyses $3^{\text {rd }}$ Ed Springer-Verlag New York, 2000, 432.

44. WHO, Guide line for drinking water quality, $2^{\text {nd }} E d ., 1996,2,940-951$.

45. Hassan F M, Al-Saadi H A, Al-Haidari M G and Hamed H A, Environmental Research and Sustainable Development, 2005, 5, 56.

46. Sabri A W, Rasheed K A and Kassim T I, Wat Res., 1997, 27(6), 1099.

47. Al-Lami, A A, Sabri, A W, Kassim, T I and Rasheed K A, Acta Hydrobiol., 1996, 38(3/4), 77

48. Lind O T, Handbook of common methods in limnology, $2^{\text {nd }}$ Ed. The C.V. Mosby Co, St. Louis., 1979, 199.

49. Maulood B K and Al-Mousawi A H, Basrah J Agric Sci., 1989, 21(1,2), 113.

50. Gachter R, Steingruber S M, Reinhardt M and Wehrli B, Aquat Sci., 2004, 66, 117.

51. Antoine S E and Al-Saadi H A, Int Revue ges Hydrobiol., 1982, 67(3), 405.

52. Weiner E R, Application of environmental chemistry, Lewis Publishers, London, New York, 2000, 347.

53. Goldman C R and Horne A J, Limnology-Megraw Hillint. B. Co., U.S.A., 1983.

54. Abaychi J K and DouAbul A A Z, Water Res., 1985, 19(4), 457.

55. Abaychi J K and Mustafa Y Z, J Biol Sci Res., 1988, 18(2), 123.

56. Al-Taee M M, Alkhateeb A N, Hussein F Hand Abid F M, Asian J Chem., 2007, 19, 741.

57. AL-Saad H T, Mustafa Y Z and AL-Timeri A, Marina Mesopotamica, 1994, 9(2), 323.

58. Nakanishi Y, Sumita M, Yumita K, Yamada T and Honjo T, Anal Sci., 2004, $20,73$.

59. Mito S, Sohrin Y, Norisuye K, Matsui M, Hasegawa H, Maruo M, Tsuchiya M and Kawashima M, Limnol., 2004, 5, 7.

60. Kaiser E, Arscott D.B, Tockner K and Sulzberger B, Aquat Sci., 2004, 66, 103.

61. Bentivegna C S, Alfano J E, Bugel S M and Czechowicz K, Urban Habitats, 2004, 2(1), 91.

62. Asonye C C, Okolie N P, Okenwa E E and Lwuanyanwu U G, African J Biotechnol., 2007, 6(5), 617. 


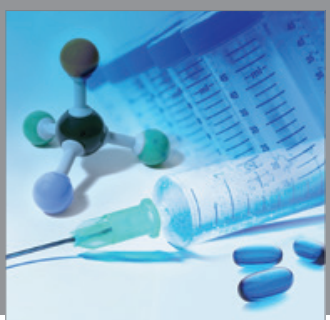

International Journal of

Medicinal Chemistry

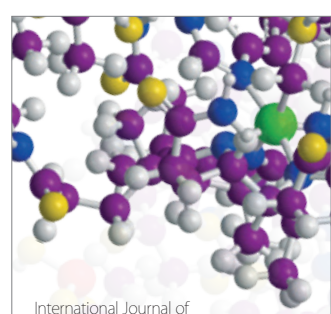

Carbohydrate Chemistry

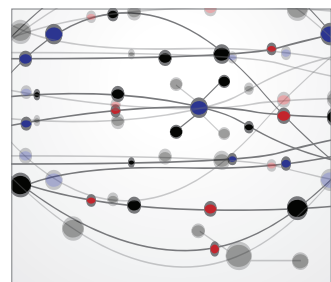

The Scientific World Journal
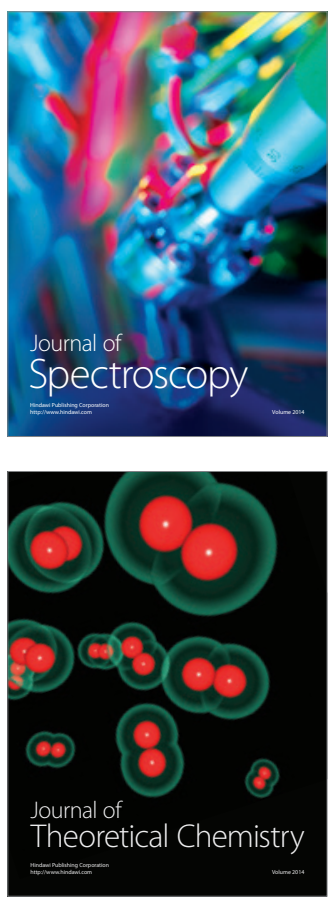
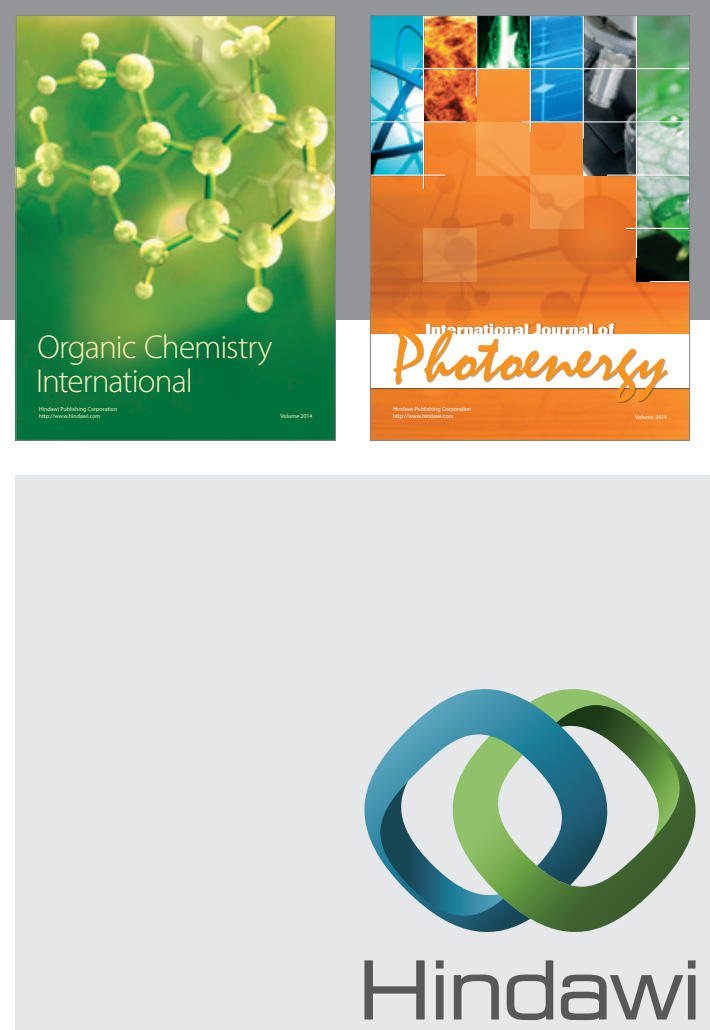

Submit your manuscripts at

http://www.hindawi.com
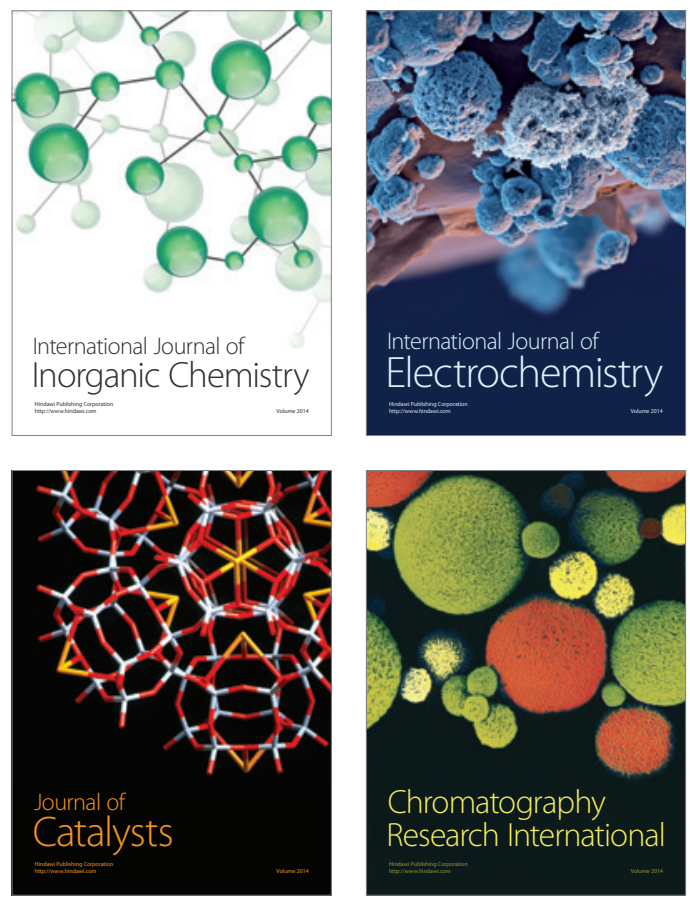
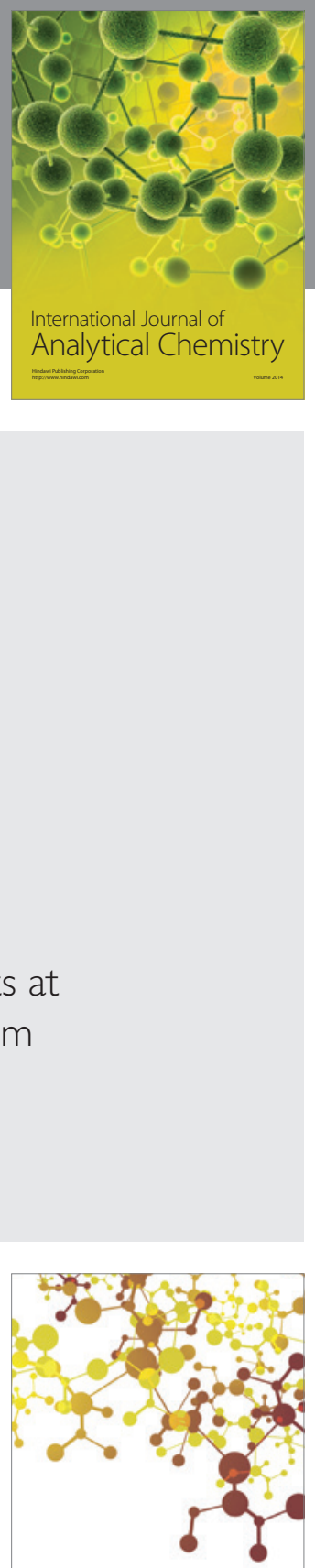

Journal of

Applied Chemistry
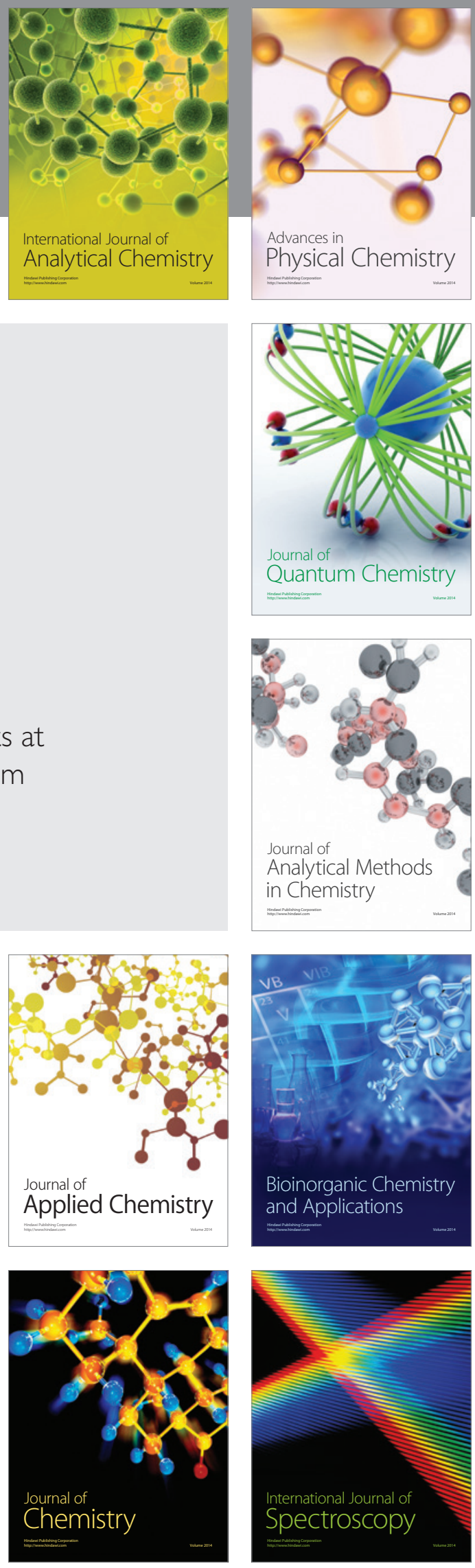